\title{
THEORETICAL AND EXPERIMENTAL INVESTIGATION OF A CATAMARAN RESISTANCE
}

\author{
Dan Obreja \\ "Dunarea de Jos" University of Galati, \\ Faculty of Naval Architecture, Galati, Domneasca \\ Street, No. 47, 800008, Romania, \\ E-mail:dan.obreja@ugal.ro
}

\author{
George-Ciprian Iatan \\ "Dunarea de Jos" University of Galati, \\ Faculty of Naval Architecture, Galati, Domneasca \\ Street, No. 47, 800008, Romania, \\ E-mail: ciprianiatan@yahoo.com
}

\begin{abstract}
A comparative theoretical and experimental analysis over catamaran resistance was developed in this paper. The theoretical estimation was performed on the basis of Sahoo method, typical for the round bilge catamarans with high speed. Experimental model tests were developed in the Towing Tank of "Dunarea de Jos" University of Galati, both with the demihull and the full catamaran, with blocked sinkage and trim, to study the influence of the hulls interference. Also, catamaran model tests with free trim were realized. In order to transpose the model results at full scale, the ITTC 1957 method was applied. The conclusions reveal significant differences between the theoretical and experimental results.
\end{abstract}

Keywords: catamaran resistance, theoretical estimation, experimental model tests

\section{INTRODUCTION}

The catamaran resistance problem is very important from the point of view of the power-speed performance.

In the initial design stage, an accurate resistance estimation is necessary. In the case of a catamaran with high speed and round bilge, the method proposed by Sahoo et al. ([5], [6]) can be used. A computer code was developed in the Research Centre of the Naval Architecture Faculty from "Dunarea de Jos" University of Galati ([4]). A practical evaluation of the catamaran resistance was performed.

In order to validate the theoretical prognosis, experimental model tests were realised in the Towing Tank of the Naval Architecture Faculty from "Dunarea de Jos" University of Galati (Photo 1), by using the ITTC Recommended Procedures [2].

The main dimensions of the Towing Tank are $45 \times 4 \times 3 \mathrm{~m}$. The characteristics of the catamaran and of the experimental model may be seen in Table 1. The experimental model (Photo 2) was manufactured on a scale of $1 / 20$, having the maximum length of $1.425 \mathrm{~m}$.

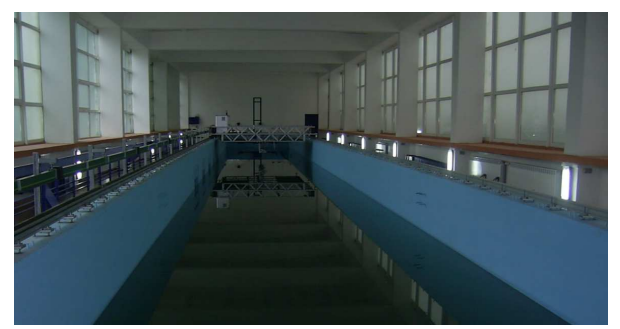

Photo 1. Towing tank of "Dunarea de Jos" University of Galati

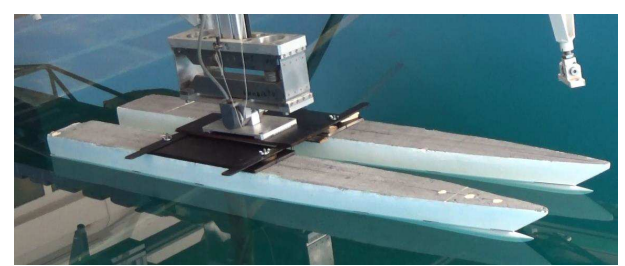

Photo 2. Catamaran model

In order to analyse the influence of the hulls interference, both the demihull and catamaran tests were performed, with blocked 
sinkage and trim. Also, catamaran model tests with free trim were developed and transposed at full scale, in order to compare the theoretical and experimental results.

Table 1. Main characteristics of the catamaran

\begin{tabular}{|l|c|c|}
\hline \hline \multicolumn{1}{|c|}{ Main characteristics } & $\begin{array}{c}\text { Full } \\
\text { scale }\end{array}$ & $\begin{array}{c}\text { Model } \\
\text { scale } \\
1 / 20\end{array}$ \\
\hline \hline Length overall, $L_{O A}[\mathrm{~m}]$ & 28.5 & 1.425 \\
\hline Length of waterline, $L_{W}[\mathrm{~m}]$ & 27.3 & 1.365 \\
\hline Beam of the catamaran, $B$ [m] & 8.0 & 0.40 \\
\hline $\begin{array}{l}\text { Beam of waterline for demihull, } \\
\mathrm{B}_{\text {demi }}[\mathrm{m}]\end{array}$ & 2.486 & 0.124 \\
\hline Depth, $D[\mathrm{~m}]$ & 2.30 & 0.115 \\
\hline Draft, $T$ [m] & 1.20 & 0.060 \\
\hline $\begin{array}{l}\text { Distance between the centerlines } \\
\text { of the demihulls, } \mathrm{s}[\mathrm{m}]\end{array}$ & 5.40 & 0.270 \\
\hline $\begin{array}{l}\text { Longitudinal center of buoyancy, } \\
L C B \text { [m] }\end{array}$ & 11.445 & 0.572 \\
\hline Half angle of entrance, $i_{E}[$ deg. $]$ & 9.5 & 9.5 \\
\hline $\begin{array}{l}\text { Deadrise angle at amidships, } \beta \\
\text { [deg.] }\end{array}$ & 26.0 & 26.0 \\
\hline $\begin{array}{l}\text { Volumetric displacement of the } \\
\text { catamaran, } \nabla\left[\mathrm{m}^{3}\right]\end{array}$ & 66.8 & 0.00835 \\
\hline $\begin{array}{l}\text { Bare hull wetted surface of the } \\
\text { catamaran, } S \text { [m }{ }^{2} \text { ] }\end{array}$ & 172.0 & 0.430 \\
\hline Design speed, $v$ [m/s] & 11.11 & 2.484 \\
\hline Froude number, $F_{n}$ & 0.679 & 0.679 \\
\hline Block coefficient, $C_{B}$ & 0.410 & 0.410 \\
\hline Waterplane coefficient, $C_{W}$ & 0.764 & 0.764 \\
\hline Midship section coefficient, $C_{M}$ & 0.612 & 0.612 \\
\hline Prismatic coefficient, $C_{P}$ & 0.670 & 0.670 \\
\hline \hline
\end{tabular}

The ITTC 1957 method was applied, in order to transpose the experimental model results at full scale [1].

\section{THEORETICAL EVALUATION}

On the basis of the mathematical model proposed by Sahoo et al. [5], the catamaran resistance $R_{\text {Tcat }}$ can be determined by using the following relation

$$
R_{\text {Tcat }}=\frac{1}{2} C_{\text {Tcat }} \cdot \rho \cdot v^{2} \cdot S_{w}
$$

where $C_{\text {Tcat }}$ is the total resistance coefficient of the catamaran, $\rho$ is water density, $S_{w}$ is the wetted surface area of the catamaran and $v$ is the design speed.
The coefficient of the total catamaran resistance $C_{\text {Tcat }}$ can be estimated by means of the following relation

$$
C_{\text {Tcat }}=(1+\gamma \cdot k) C_{F}+C_{w c a t}
$$

where $C_{F}$ is the frictional resistance coefficient of the demihull, $C_{\text {wcat }}$ is the wave resistance coefficient of the catamaran and $(1+\gamma k)$ is the form factor of the catamaran. The last coefficient is calculated by using the expression proposed by Sahoo et al. [6], on the basis of Molland's serries [3], depending by the following parameters

$$
(1+\gamma \cdot k)=f\left(\frac{B_{\text {demi }}}{T} ; \frac{L_{W}}{\nabla_{\text {demi }}^{1 / 3}} ; \frac{s}{L_{\text {demi }}} ;(1+k)\right)
$$

where $L_{W}$ is the length of waterline, $B_{\text {demi }}$ is the beam of waterline for demihull, $T$ is the medium draft, $\nabla_{\text {demi }}$ is the volumetric displacement of the demihull, $s$ is the distance between the centerlines of the demihulls and $(1+k)$ is the form factor of the demihull.

The frictional resistance coefficients of the demihull $C_{F}$ can be calculated on the basis of ITTC'57 ship model's correlation line

$$
C_{F}=\frac{0.075}{\left(\log R_{n}-2\right)^{2}}
$$

where $R_{n}$ is the Reynolds number given by the following relation

$$
R_{n}=\frac{v \cdot L_{W}}{v}
$$

depending on the kinematic viscosity of the fluid $v$.

In order to calculate the wave resistance coefficient of the catamaran $C_{\text {wcat }}$, the relation proposed by Sahoo et al. ([5], [6]) can be used, depending by the regression coefficients $c_{i}$, the half angle of entrance $i_{E}$, the deadrise angle at amidship $\beta$ and the block coefficient $C_{B}$

$$
\begin{aligned}
& C_{\text {wcat }}=e^{c 1} \cdot\left(\frac{L_{W}}{B_{\text {demi }}}\right)^{c 2} \cdot\left(\frac{B_{\text {demi }}}{T}\right)^{c 3} \cdot\left(C_{B}\right)^{c 4} \cdot F_{1} \\
& F_{1}=\left(\frac{L_{W}}{\nabla^{1 / 3}}\right)^{c 5} \cdot\left(i_{E}\right)^{c 6} \cdot \beta^{c 7} \cdot\left(\frac{s}{L_{W}}\right)^{c 8}
\end{aligned}
$$

The restrictions of this method, presented in Table 2 are fulfilled, outside of the prismatic coefficient. 
Figure 1 depicts the diagram of the catamaran resistance. The slope of the curve increases with moderate value, in the selected domain of the speeds.

Table 2. Sahoo method. Range of parameters

\begin{tabular}{|c|c|c|}
\hline \hline Parameters & $\begin{array}{c}\text { Range of } \\
\text { parameters }\end{array}$ & $\begin{array}{c}\text { Catamaran } \\
\text { characteristics }\end{array}$ \\
\hline \hline$L_{W} / B$ & $2.76 \ldots 5$ & 3.4125 \\
\hline$B / T$ & $2.46 \ldots 19.32$ & 6.667 \\
\hline$C_{P}$ & $0.520 \ldots 0.60$ & 0.670 \\
\hline$L_{W} / \nabla^{1 / 3}$ & $4.340 \ldots 8.50$ & 6.728 \\
\hline$i_{E}$ & $4 \ldots 11$ & 9.5 \\
\hline$\beta$ & $23 \ldots 45$ & 26 \\
\hline$F_{n}$ & $0.125 \ldots 0.750$ & 0.679 \\
\hline
\end{tabular}

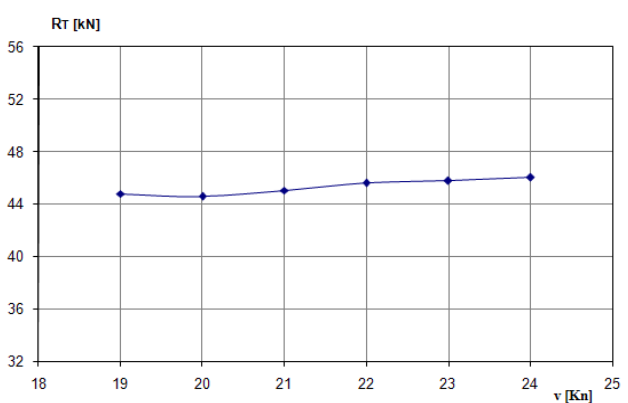

Fig. 1. Catamaran resistance diagram

The results of the experimental model tests are presented in the next chapter.

\section{MODEL TESTS RESULTS}

Experimental demihull model resistance tests were performed, with blocked sinkage and trim (Photo 3). A speed domain between $1 \mathrm{~m} / \mathrm{s}$ and $2.75 \mathrm{~m} / \mathrm{s}$ was adopted, with the increment $0.25 \mathrm{~m} / \mathrm{s}$. No turbulence device was considered.

The experimental results are presented in Table 3.

The diagram of the demihull resistance depending on the model speed are shown in Fig. 2.

The wave pattern depending by the model speed is shown in Photos 4-11.

A pronunced wake and an important influence of the transom stern with vertical margins can be observed, starting with low speeds. Also, diverging waves were generated in the forward part of the demihull. The own wave crest increases with the model speed.

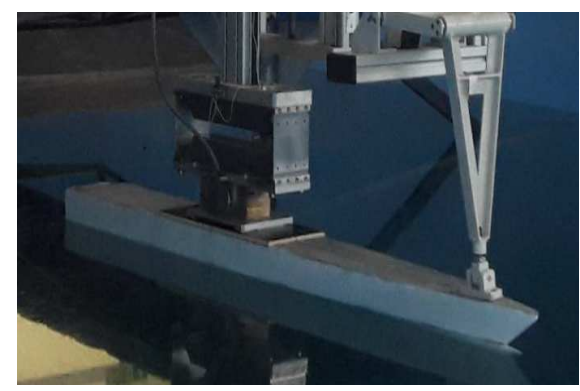

Photo 3. Demihull model

Table 3. Demihull model resistance results

\begin{tabular}{|c|c|c|}
\hline \hline $\begin{array}{c}\text { Test } \\
\text { number }\end{array}$ & $\begin{array}{c}\text { Model speed } \\
v_{m}[\mathrm{~m} / \mathrm{s}]\end{array}$ & $\begin{array}{c}\text { Demihull model } \\
\text { resistance } \\
R_{T m}[\mathrm{~N}]\end{array}$ \\
\hline \hline $\mathrm{T} 1$ & 1.0 & 0.756 \\
\hline $\mathrm{T} 2$ & 1.25 & 1.352 \\
\hline $\mathrm{T} 3$ & 1.50 & 1.664 \\
\hline $\mathrm{T} 4$ & 1.75 & 1.837 \\
\hline $\mathrm{T} 5$ & 2.0 & 2.286 \\
\hline $\mathrm{T} 6$ & 2.25 & 2.755 \\
\hline $\mathrm{T} 7$ & 2.50 & 3.250 \\
\hline $\mathrm{T} 8$ & 2.75 & 3.710 \\
\hline \hline
\end{tabular}

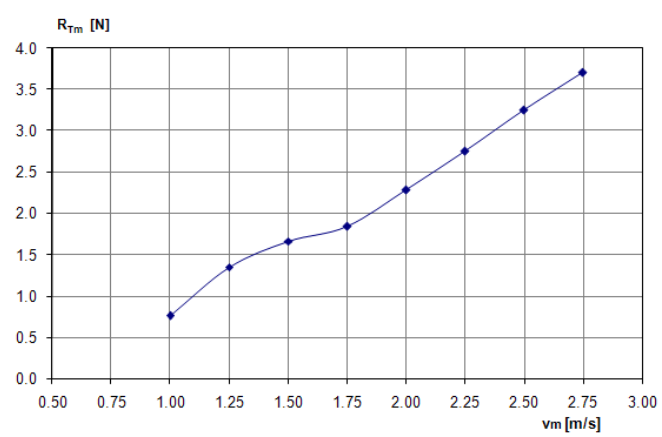

Fig. 2. Demihull model resistance diagram

Experimental catamaran model resistance tests were realized in the same conditions.

The experimental results are presented in Table 4.

The diagram of the catamaran resistance depending on the model speed are shown in Fig. 3.

The wave pattern depending by the model speed is shown in Photos 12-19. 
The Annals of "Dunarea de Jos" University of Galati
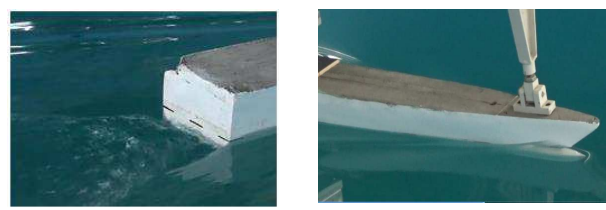

Photo 4. Wave pattern, $\mathrm{v}_{\mathrm{m}}=1.0 \mathrm{~m} / \mathrm{s}$
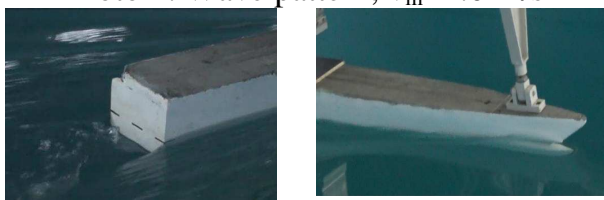

Photo 5. Wave pattern, $\mathrm{v}_{\mathrm{m}}=1.25 \mathrm{~m} / \mathrm{s}$
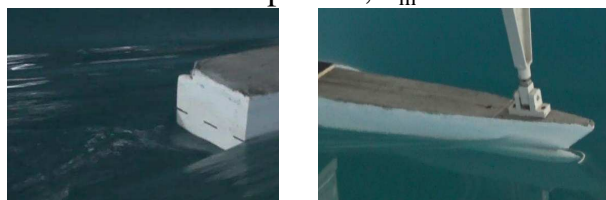

Photo 6. Wave pattern, $\mathrm{v}_{\mathrm{m}}=1.5 \mathrm{~m} / \mathrm{s}$
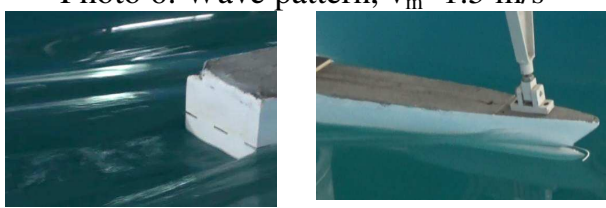

Photo 7 . Wave pattern, $\mathrm{v}_{\mathrm{m}}=1.75 \mathrm{~m} / \mathrm{s}$
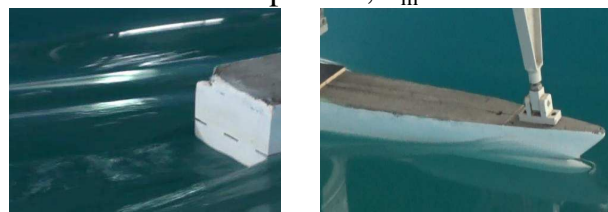

Photo 8. Wave pattern, $\mathrm{v}_{\mathrm{m}}=2.0 \mathrm{~m} / \mathrm{s}$

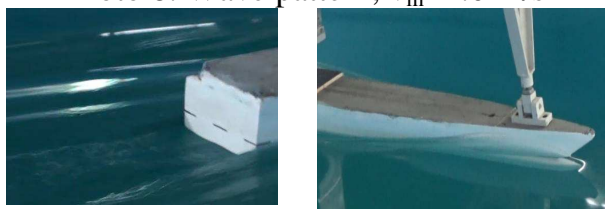

Photo 9 . Wave pattern, $\mathrm{v}_{\mathrm{m}}=2.25 \mathrm{~m} / \mathrm{s}$
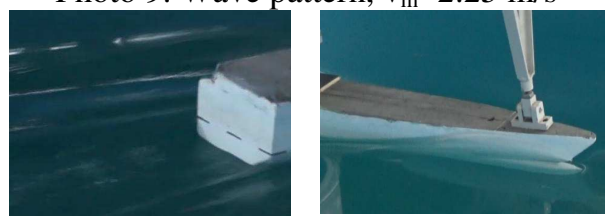

Photo 10. Wave pattern, $\mathrm{v}_{\mathrm{m}}=2.50 \mathrm{~m} / \mathrm{s}$

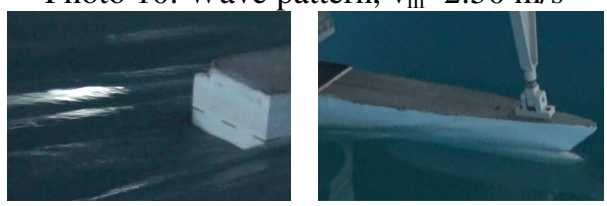

Photo 11. Wave pattern, $\mathrm{v}_{\mathrm{m}}=2.75 \mathrm{~m} / \mathrm{s}$
Table 4. Catamaran model resistance results

\begin{tabular}{|c|c|c|}
\hline $\begin{array}{c}\text { Test } \\
\text { number }\end{array}$ & $\begin{array}{c}\text { Model speed } \\
v_{m}[\mathrm{~m} / \mathrm{s}]\end{array}$ & $\begin{array}{c}\text { Catamaran model } \\
\text { resistance } \\
R_{T m}[\mathrm{~N}]\end{array}$ \\
\hline \hline $\mathrm{T} 1$ & 1.0 & 1.872 \\
\hline $\mathrm{T} 2$ & 1.25 & 2.266 \\
\hline $\mathrm{T} 3$ & 1.50 & 3.271 \\
\hline $\mathrm{T} 4$ & 1.75 & 4.427 \\
\hline $\mathrm{T} 5$ & 2.0 & 5.733 \\
\hline $\mathrm{T} 6$ & 2.25 & 6.856 \\
\hline $\mathrm{T} 7$ & 2.50 & 8.102 \\
\hline $\mathrm{T} 8$ & 2.75 & 9.966 \\
\hline \hline
\end{tabular}

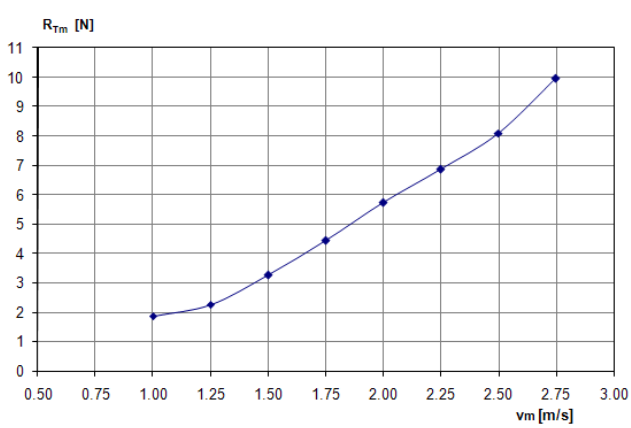

Fig. 3. Catamaran model resistance diagram
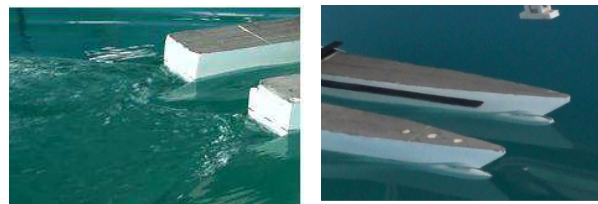

Photo 12 . Wave pattern, $\mathrm{v}_{\mathrm{m}}=1.0 \mathrm{~m} / \mathrm{s}$

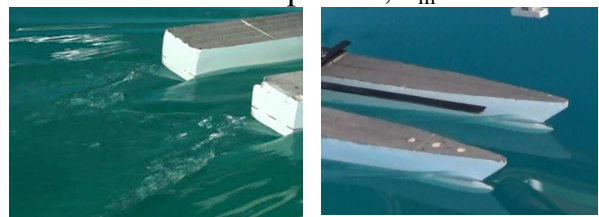

Photo 13. Wave pattern, $\mathrm{v}_{\mathrm{m}}=1.25 \mathrm{~m} / \mathrm{s}$

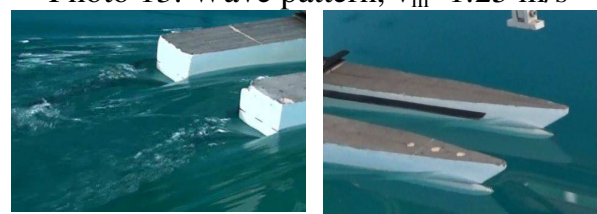

Photo 14. Wave pattern, $\mathrm{v}_{\mathrm{m}}=1.5 \mathrm{~m} / \mathrm{s}$

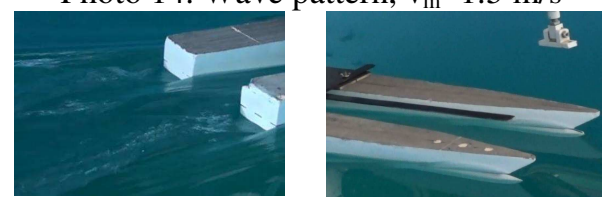

Photo 15 . Wave pattern, $\mathrm{v}_{\mathrm{m}}=1.75 \mathrm{~m} / \mathrm{s}$ 

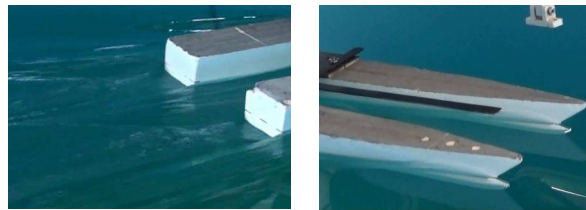

Photo 16. Wave pattern, $\mathrm{v}_{\mathrm{m}}=2.0 \mathrm{~m} / \mathrm{s}$
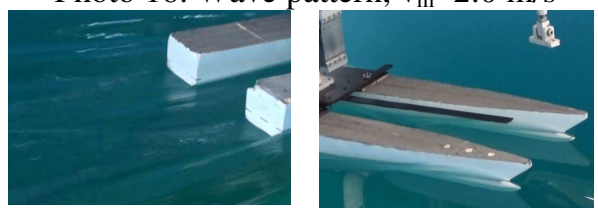

Photo 17. Wave pattern, $\mathrm{v}_{\mathrm{m}}=2.25 \mathrm{~m} / \mathrm{s}$
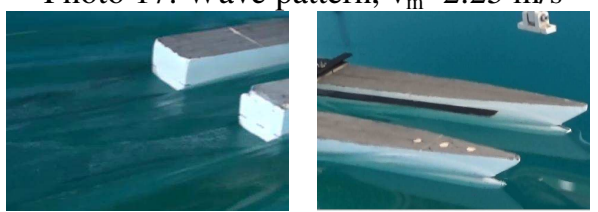

Photo 18. Wave pattern, $\mathrm{v}_{\mathrm{m}}=2.50 \mathrm{~m} / \mathrm{s}$
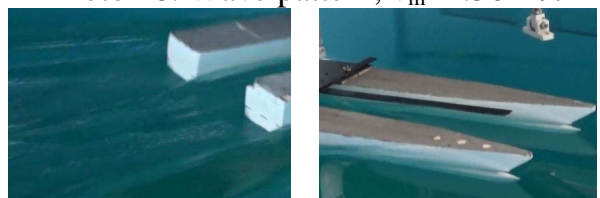

Photo 19. Wave pattern, $\mathrm{v}_{\mathrm{m}}=2.75 \mathrm{~m} / \mathrm{s}$

Significant wave trough was produced due to the diverging waves generated and reflected by the demihulls.

In the same time, the interaction between the own waves behind the transom stern generates a wave crest with large amplitude, in the analysed speed domain.

Catamaran model tests with blocked sinkage but free trim were developed. The experimental results are presented in Table 5.

Table 5. Catamaran model resistance results with free trim

\begin{tabular}{|c|c|c|}
\hline \hline $\begin{array}{c}\text { Test } \\
\text { number }\end{array}$ & $\begin{array}{c}\text { Model speed } \\
v_{m}[\mathrm{~m} / \mathrm{s}]\end{array}$ & $\begin{array}{c}\text { Catamaran model } \\
\text { resistance } \\
R_{T m}[\mathrm{~N}]\end{array}$ \\
\hline \hline $\mathrm{T} 1$ & 1.0 & 1.80 \\
\hline $\mathrm{T} 2$ & 1.25 & 2.278 \\
\hline $\mathrm{T} 3$ & 1.50 & 3.322 \\
\hline $\mathrm{T} 4$ & 1.75 & 4.657 \\
\hline $\mathrm{T} 5$ & 2.0 & 5.952 \\
\hline $\mathrm{T} 6$ & 2.25 & 6.741 \\
\hline $\mathrm{T} 7$ & 2.50 & 7.660 \\
\hline $\mathrm{T} 8$ & 2.75 & 8.792 \\
\hline \hline
\end{tabular}

The diagram of the catamaran resistance with free trim depending on the model speed are shown in Fig. 4.

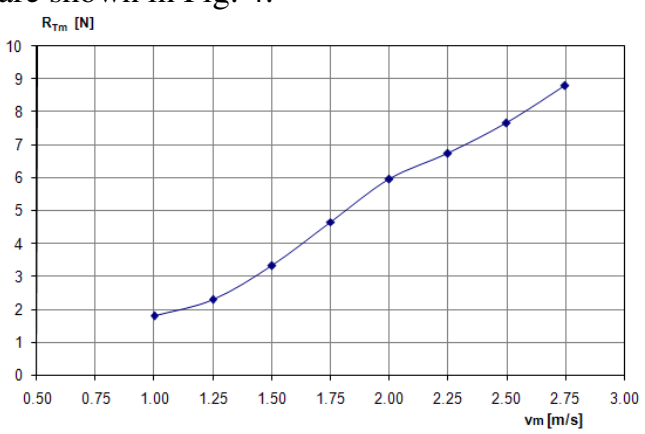

Fig. 4. Free trim catamaran model resistance diagram

A comparison between the demihull and catamaran resistance is presented in Fig. 5.

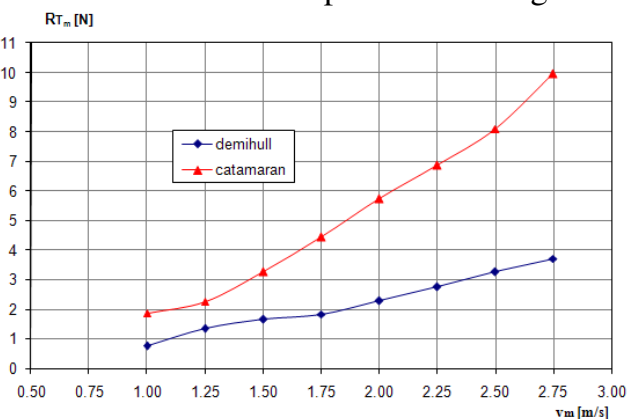

Fig. 5. Demihull and catamaran model resistance diagram

Starting with the model speed equal with $1.5 \mathrm{~m} / \mathrm{s}$ the catamaran model resistance is greater than twice value of the demihull model resistance, due to the interference phenomenon.

The ITTC 1957 method was applied in order to transpose, at full scale, the catamaran model resistance obtained in the case of free trim. The full scale results obtained on the basis of model tests are shown in Table 6 .

A comparison between the theoretical and transposed catamaran resistance results is presented in Table 7 and Fig. 6.

Significant differences between the theoretical and experimental results can be observed. 
Table 6. Full scale catamaran resistance with free trim (transposing model results)

\begin{tabular}{|c|c|c|c|}
\hline \hline $\begin{array}{c}\text { Test } \\
\text { number }\end{array}$ & $\begin{array}{c}\text { Model } \\
\text { speed } \\
v_{m}[\mathrm{~m} / \mathrm{s}]\end{array}$ & $\begin{array}{c}\text { Catamaran } \\
\text { speed } \\
v[\text { Knots }]\end{array}$ & $\begin{array}{c}\text { Catamaran } \\
\text { resistance } \\
R_{\text {Texp }}[\mathrm{kN}]\end{array}$ \\
\hline \hline $\mathrm{T} 1$ & 1.0 & 8.69 & 10.809 \\
\hline $\mathrm{T} 2$ & 1.25 & 10.87 & 12.991 \\
\hline $\mathrm{T} 3$ & 1.50 & 13.04 & 19.459 \\
\hline $\mathrm{T} 4$ & 1.75 & 15.21 & 28.023 \\
\hline $\mathrm{T} 5$ & 2.0 & 17.39 & 36.043 \\
\hline $\mathrm{T} 6$ & 2.25 & 19.56 & 39.796 \\
\hline $\mathrm{T} 7$ & 2.50 & 21.73 & 44.383 \\
\hline $\mathrm{T} 8$ & 2.75 & 23.91 & 50.473 \\
\hline \hline
\end{tabular}

Table 7. Full scale catamaran resistance. Theoretical and transposed results

\begin{tabular}{|c|c|c|}
\hline $\begin{array}{c}\text { Catamaran } \\
\text { speed } \\
v \text { [Knots] }\end{array}$ & $\begin{array}{c}\text { Theoretical } \\
\text { catamaran } \\
\text { resistance } \\
R_{\text {Th }}[\mathrm{kN}]\end{array}$ & $\begin{array}{c}\text { Transposed } \\
\text { catamaran } \\
\text { resistance } \\
R_{\text {Texp }}[\mathrm{kN}]\end{array}$ \\
\hline \hline 19 & 44.790 & 38.994 \\
\hline 20 & 44.599 & 40.632 \\
\hline 21 & 45.066 & 42.706 \\
\hline 22 & 45.590 & 45.050 \\
\hline 23 & 45.788 & 47.751 \\
\hline 24 & 46.014 & 50.732 \\
\hline
\end{tabular}

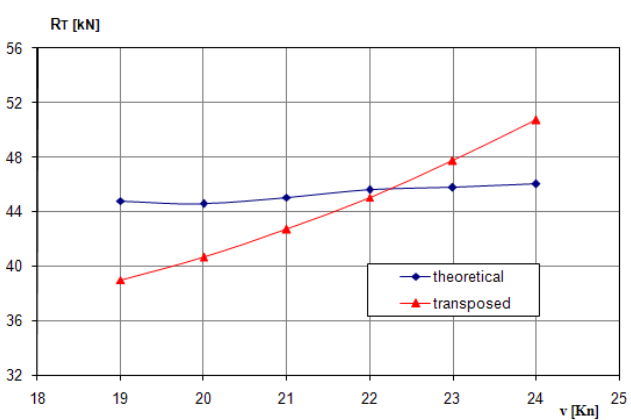

Fig. 6. Catamaran resistance diagram at full scale

\section{CONCLUDING REMARKS}

The catamaran resistance was investigated in this paper, by using theretical and experimental methods.

From theoretical view point, the method of Sahoo was applied.

Experimental resistance tests with demihull and catamaran models were developed and the negative influence of the hulls interference was demonstrated.
Also, significant differences between the theoretical and experimental results have been highlighted.

As a consequence, is necessary to increase the accuracy of the catamaran resistance prediction methods, specially in the case of high speeds domain.

\section{Acknowledgements}

The research was supported by the Naval Architecture Faculty, in "Dunarea de Jos" University of Galati.

The catamaran's body lines plan has been provided by Dr. Eng. Ovidiu Ionas, technical director of the company Ship Design Groupe Galati, to whom we are grateful.

\section{REFERENCES}

[1]. Bertram, V., "Practical Ship Hydrodynamics", Butterworth Heinemann, Oxford, 2000.

[2]. ITTC Recommended Procedures and Guidelines 7.5-02.02.01, "Testing and Extrapolation Methods. Resistance Test”, $23^{\text {rd }}$ ITTC, 2002.

[3]. Molland, A.F., Wellicome, J.F., Couser, P.R., "Resistance experiments on a systematic series of high speed displacement catamaran forms: variation of lengthdisplacement ratio and breadth-draft ratio", Ship Science Report, No. 71, University of Southampton, UK, 1994.

[4]. Obreja, C.D., Chiracu, D.I., "Practical evaluation of high-speed round bilge catamaran resistance", The Annals of "Dunarea de Jos" University of Galati, Galati University Press, pp. 21-26, 2015.

[5]. Sahoo, P.K., Brown, N.A., Salas, M., “ $E x$ perimental and CFD study of wave resistance of high-speed round bilge catamaran hull forms", Proceedings of $4^{\text {th }}$ International Euro Conference on High Performance Marine Vehicles, Rome, Italy, 2004.

[6]. Sahoo, P.K., Salas, M., Schwetz, A., Practical evaluation of resistance of high-speed catamaran hull forms-part I", Ships and offshore structures, Vol.2, Issue 4, pp. 307-324, 2007.

Paper received on December $14^{\text {th }}, 2018$ 